\title{
Ecological Role of Micro-Organisms on Surface Deterioration of Cross River Basalt Monoliths in Nigeria
}

\author{
Abu S. EDET \& Hidenori TAKAHASHI Graduate School of Environmental Earth Science, Hokkaido \\ University, Sapporo 060-0810, Japan. \\ Taro SEKI Faculty of Science, Hiroshima University, Higashi-hiroshima 039-0046, Japan.
}

\begin{abstract}
Biological growth on the surface of basalt rock monoliths by a wide variety of microorganisms including bacteria, (fungi and algae), lichens, mosses and liverworts were studied. Microscopic identification, quantification and an ecological classification of the micro-organisms on two different sites were made to aid the study of their implication in crack and pitting observed on monoliths surface. The result of this study reveal significant differences and some similarities in growth between the chosen sites and the existence of some of the micro-organisms family species in Japan. A complex biotic chemical weathering on the surface of the monoliths was distinguished. Over 450 of the cylindrical monoliths are affected. The communities in this region regard the monolith to represent their ancestors. The monoliths are monuments protected as important cultural property of national interest.
\end{abstract}

Key words: basalt monolith / deterioration / cultural properties / deforestation

This study is part of an interdisciplinary research work aimed at evaluating the potential impacts of micro-organisms on the rocks commonly called the Cross River monoliths located in the Cross River region of Nigeria (Fig. 1). The actions of micro-organisms and the characteristics of the environment in which the monoliths are affected were both considered. The micro-organisms identified as promoting weathering activities are bacteria, algae, fungi, lichen, mosses and liverworts. Two sites were chosen for this study, Alok open grassland and Old Nkrigom closed forest Biological growth differ according to ecological peculiarities. This undesired effects on the monolith is a cause for concern to the conservator while the ecologist would be delighted in seeing the survival of the wide range of growth variety. The analysis of the relationship between environmental conditions, the monoliths and micro-organisms is the basis of understanding the mechanisms of crack and pitting occurrence on the monoliths surface.

\section{SIGNIFICANCE OF STUDY}

The significance of the monoliths remains in their values as a cultural property. Before 1945 there were reports about the existence of decorated Cross River monoliths in the forest region of the Cross River (Allison 1968) conducted ethnographic research and documentation of the monoliths. He reported on broken monoliths with deep cracks, flakes and microgrowth. He also reported on deteriorated monoliths on grassland due to 'annual fires'. Many plants in this area have been 

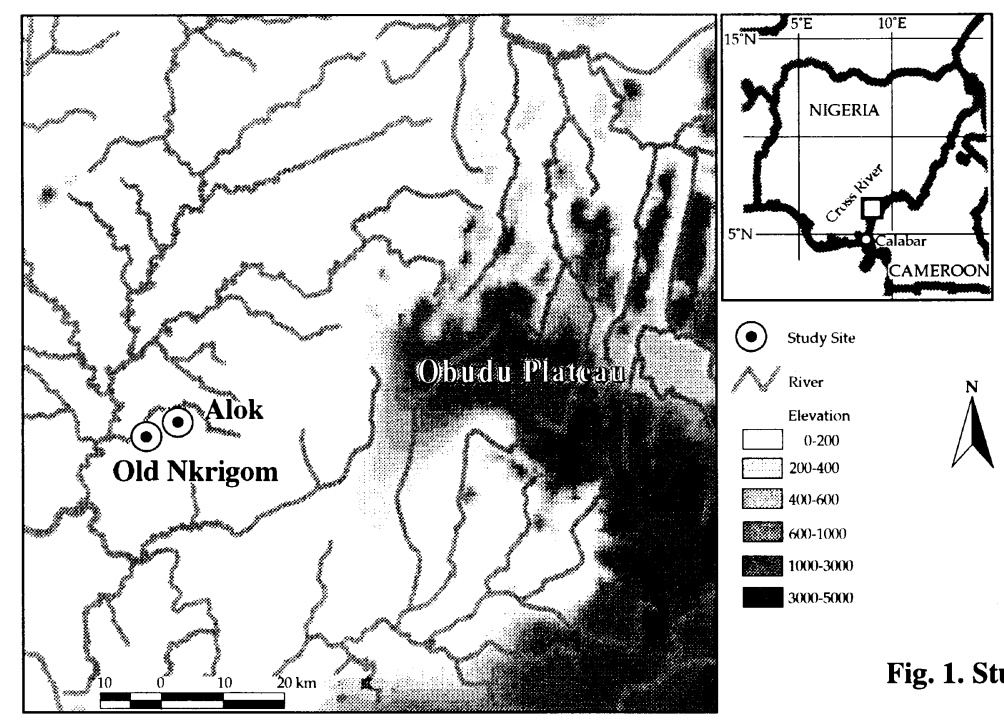

$\bigcirc$ study site

$N_{\text {River }}$

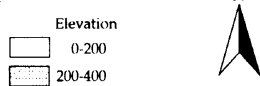

$400-400$

(2)

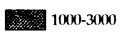

Cono-5000

Fig. 1. Study sites.

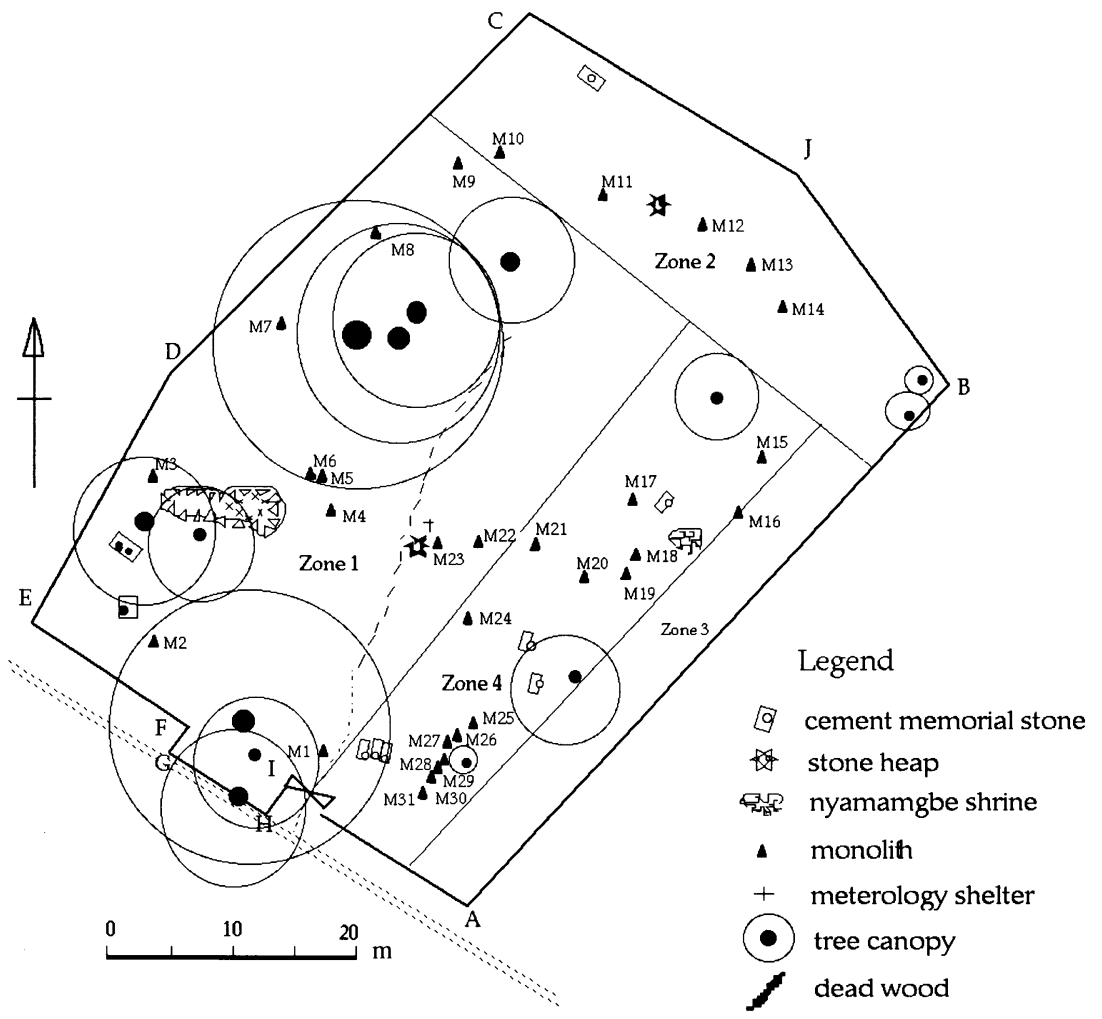

Fig. 2. Alok open forest. - shrubs cut down to make monoliths visible. - over maturity or trees indicate forest before it was cleared. - bahamas grass planted to replace wild grass. - site fenced round to guard against fire and theft. 


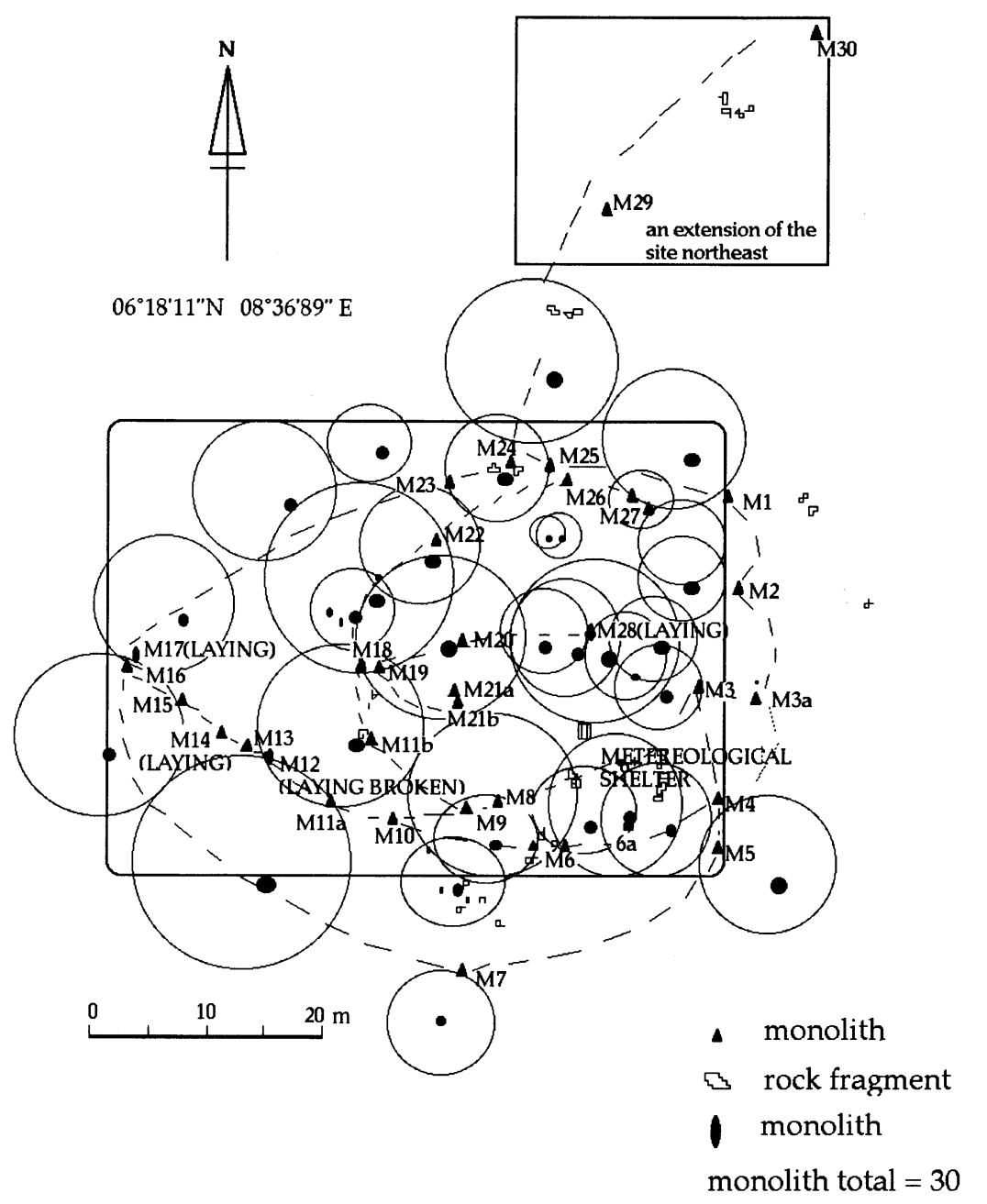

Fig. 3 Old Nkrigom ground map showing site location of monoliths, rock fragments and canopies.

associated with Central rather than West African species (Udo, 1970).

\section{STUDY SITES}

\section{Alok site Location and Topography}

Alok site is located at $06^{\circ} 19^{\prime} 22^{\prime \prime} \mathrm{N}, 08^{\circ} 38^{\prime} 08^{\prime \prime} \mathrm{E}$, the topography is 300 meters above sea level, characterized by undulating terrain with gentle slope which allow gentle surface water drainage with no soil erosion damage to the site (Fig. 2). The vegetation consisted of scattered trees with an under storey of grasses and herbs. Partial interception of rain affects zone 1 because of the large silk cotton canopies. Zones 2, $3 \& 4$ are open to direct rain impact. Gentle wind blows almost continuously, particularly during the day. The monoliths consist of shaped and decorated basalt and sandstone rock. They vary in size and shape, 30 centimeters, to columns over 1.5 meters high and weighing 100 to 
$800 \mathrm{~kg}$.

\section{Old Nkrigom Site Location and Topography}

Old Nkrigom is located at $06^{\circ} 18^{\prime} 11^{\prime \prime} \mathrm{N}, 08^{\circ} 36^{\prime} 89^{\prime \prime} \mathrm{E}$, the topography is 150 meters above sea level, located in the low land of the Cross River Basin (Fig. 3). The site is dominated by different species of trees. The trees interpose a barrier between the atmosphere and the ground surface and much of the solar heat is absorbed by the canopies thus diminishing the extremes of the temperature and narrowing temperature ranges. Prolonged damp conditions induces high growth of microorganisms. During the dry season, water-table drawdown reduces the waterlogged soil conditions. The heavy shrubs, canopies, creepers and overhanging trees may locally modify the weathering environment. The intense biological activity are mainly accumulation of bacteria, fungi and algae and other organisms such as mosses and liverworts.

\section{ENVIRONMENTAL CONDITION OF THE SITES}

Climate a major long term factor was considered as relevant parameters among which are rainfall, temperature, sunshine and wind. Environmental influences jointly and continuously affect the micro organisms which grow in mutual relationship with other individual of the same or of different species. Solar radiation is strongest during the dry season November (Fig. 4a). Temperature difference between Alok and Old Nkrigom was greater during the harmattan (November and December). This may be associated with the activities of the local weather system (Fig. 4b).

Light favor more growth of lichen in Alok. In Old Nkrigom, not much lichen growth was observed because of the condition of low lighting due to heavy canopy cover. Photosynthetic activity on both side vary due to the quantity and quality of light which was observed as a limiting factor. Solar radiation in the forest was around $20 \%$ of the open site (Fig. 4a). High temperature during the dry season causes dryout of the water content on the monolith surface at Alok. The total amount of annual rainfall in this region reached $2000 \mathrm{~mm}$, which is enough to keep the tropical rain forest in this area. But dry season with monthly rainfall less than $100 \mathrm{~mm}$ begin in November and end in March. Total amount of rainfall in dry season, November to March was $100 \mathrm{~mm}$ (10\% of annual total). Rainy season continues 7 months from April to October (Fig. 4c). High humidity enables bacteria, lichens, mosses and liverworts growth. Low humidity in the dry season promotes the dry-out of the monolith surface particularly in Alok site. Relative humidity during the rainy season on average $96 \%$, and the dry season on average $85 \%$ Daily fluctuation from $98-80 \%$.

\section{IDENTIFICATION OF MICRO-ORGANISMS}

Samples of the different species were collected in paper bags, air dried, and stored in room temperature. The specimens were prepared and identified using optical microscope and photomicrography. The micro-organism species identified: (Fig. 5a-h and Table 1).

1. Tridax procumbens $\mathrm{L}$. (Asteraceae) Original in tropical America. It has been broadly naturalized in tropical area. It was naturalized in Okinawa after the War.

2. Mosses Octoblepharum albidum Hedw. (Bryopsida, Musci) identified with Old Nkrigom Palm 

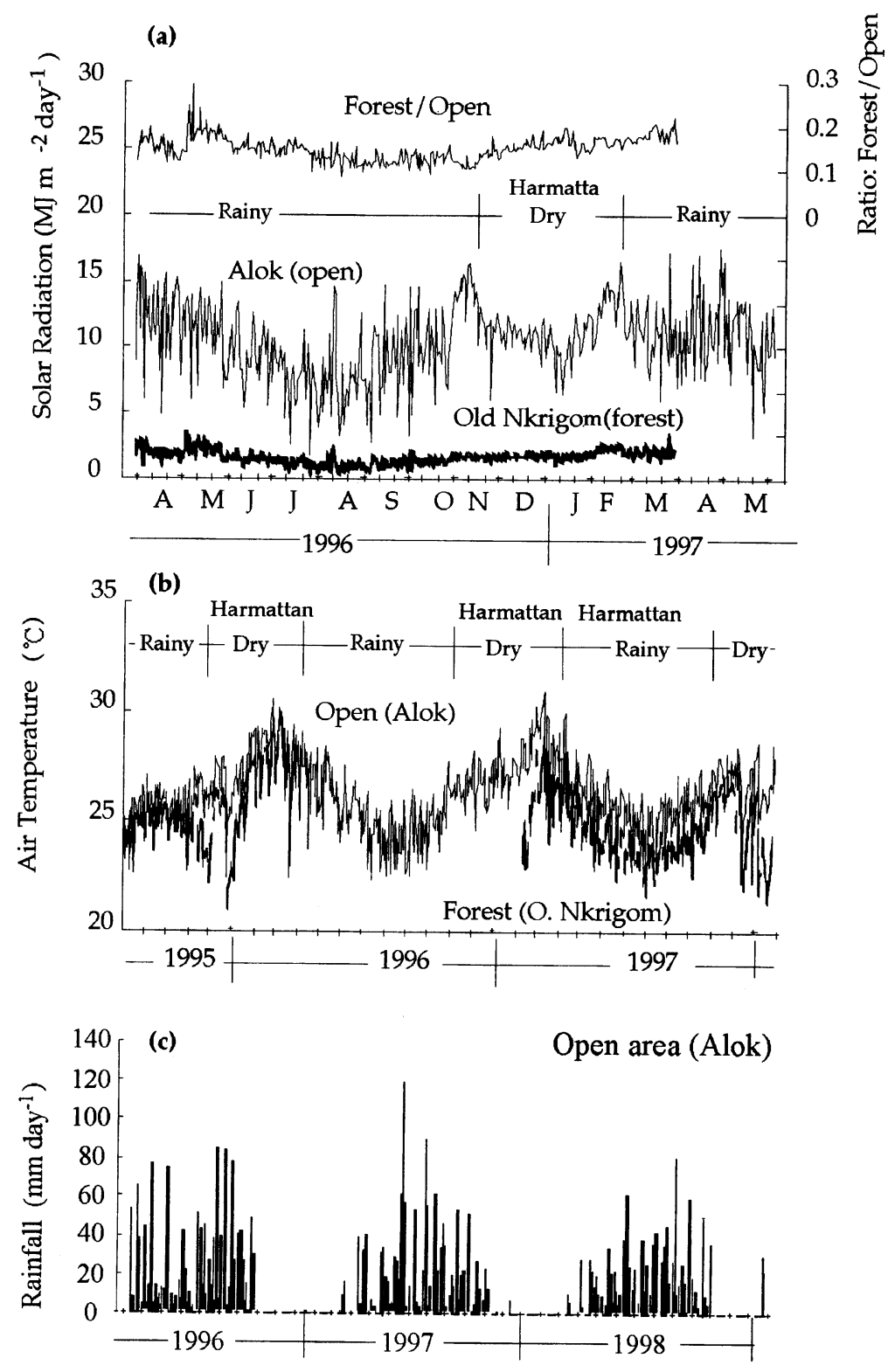

Fig. 4. Seasonal change of climate.

a: Solar radiation in the forest and open site,

b: Daily mean air temperature in the forest and the open site,

c: Rainfall in the open area.

Tree-1. They are also distributed in South-east Asian, but unknown in Japan.

3. Mosses Syrrhopondon sp. One species in genus Syrrhopondon (Calymeracea). This genus has a wide distribution in tropical and subtropical area. Some species are also found in south-west Japan. It has been identified as Syrrhopodon species.

4. Mosses Hyophila involuta (Hook) Jaeg. (Pottiaceae) It is broadly distributed in tropical and 

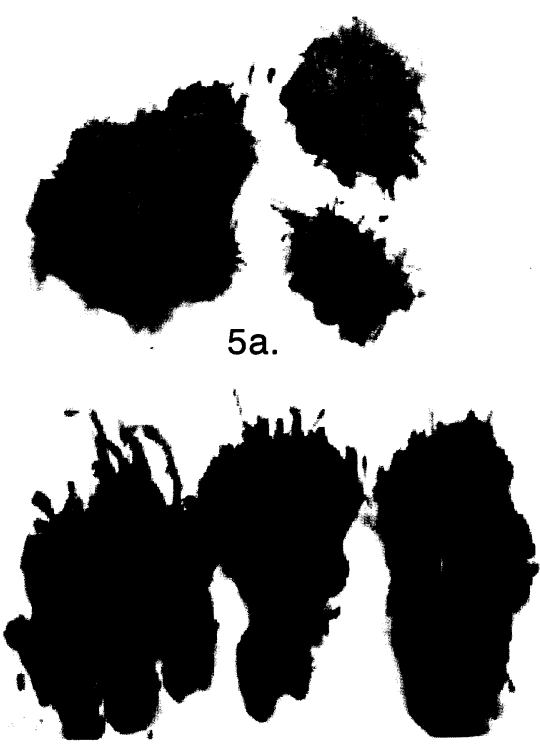

$5 c$.

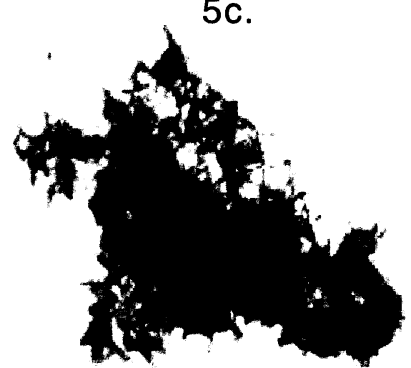

$5 e$.

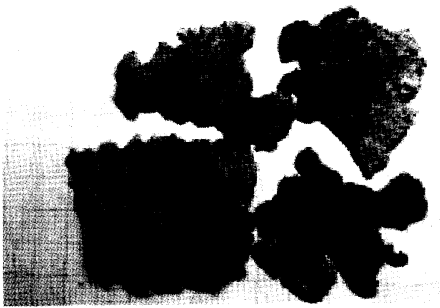

$5 g$.

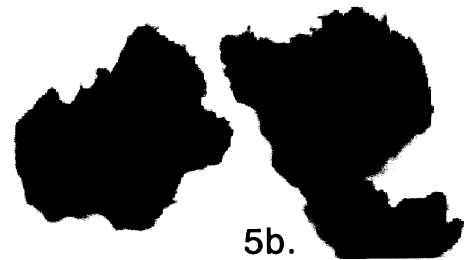

$5 b$.

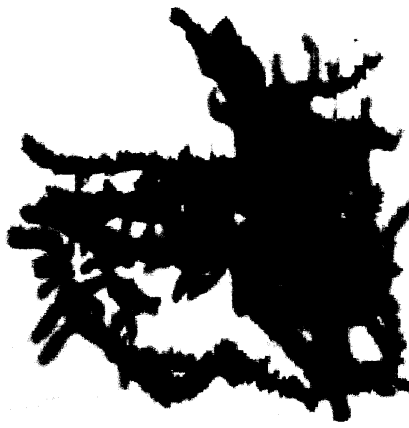

$5 d$.

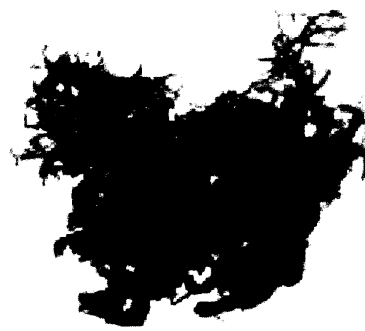

$5 f$.

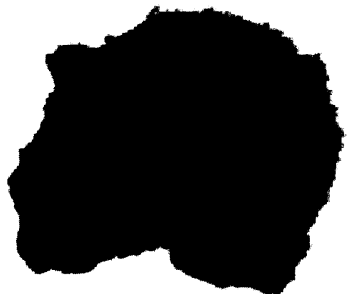

$5 \mathrm{~h}$.

Figs. 5 a-h. Photomicrograph of micro-organisms identified at two sites Alok and Old Nkrigom.

5a. Mosses (Bryopsida Musci).

5c. Mosses (Calymeraceae).

5b. Mosses genus Syrrhopodon (Calymperaceae)

5e. Mosses Thuidium sp. (Thuidiaceae)

5d. Mosses Stereophyllum radiculosum ( Plagoitheciaceae)

5g. Lichens Parmelia sp. (Parmeliaceae).

5f. Liverworts Lopholejeunea sp. (Lejeuneaceae).

5h. Mosses Hyophila involuta (Hook) Jaeg. (Pottiaceae).

Table 1. Show the number of micro-organisms and the type of species identified as growing on both monolith and tree barks in Alok and Old Nkrigom sites.

\begin{tabular}{lcccc}
\hline \multicolumn{5}{c}{ MICRO-ORGANISMS } \\
\hline Species & \multicolumn{2}{c}{ Alok } & \multicolumn{3}{c}{ Old N krigom } \\
\hline Mosses & monolith & tree & monolith & tree \\
Lichens & 2 & 1 & 3 & \\
Liverworts & 3 & - & 3 & 1 \\
\hline
\end{tabular}


subtropical area, and is also found in south-west Japan. Identified with Alok M23 monolith.

5. Mosses Stereophyllum radiculosum (Hook) Mitt. (Plagiotheciaceae). Identified with Old Nkrigom palm tree on the forest periphery (out-12). This genus is mainly distributed in central America. It is not found in Japan. It is noted as Stereophyllum species.

6. Mosses Thuidium sp. (Thuidiaceae). This genus distribute from sub-frigid zone to tropical zone. There are also many species is Japan.

7. Mosses Thuidium sp. (Thuidiaceae) Mosses + Syrrophodon species + Lopholejeunea species. Identified with Old Nkrigom Tree-1.

8. Liverworts Lejeunea sp. (Lejeuneaceae). Old Nkrigom monolith. This genus distribute from temperate to tropical area. There are many species. There are about 15 species in Japan. Most of them grow on the tree or rock.

9. Liverworts Lopholejeunea sp. (Lejeuneaceae). Tropical vegetation, and three species grow in Japan. Identified with Old Nkrigom (M. 2) monolith.

10. Lichens Parmelia sp. (Parmeliaceae). This genus is the representative of folioe lichens, and broadly distributed in the world. There are too many species, and it is difficult to classify them. There are 78 species in Japan. Identified with Alok (M. 23) (2). Monolith.

11. Lichens Parmelia sp. (Parmeliaceae). Identified with Alok M. 23 (3). monolith.

12. Lichens Parmelia sp. Crustouse lichens. Identified with Old Nkrigom -1 monolith.

13. Lichens Pyrenula sp. One species in genus Pyrenula. (Pyrenulaceae). Identified with Old Nkrigom M.2 (2) monolith.

14. Lichens Physcia sp. One species in genus Physcia. (Physciaceae) + Crustouse lichens. Identified with Alok M. 23 (1).

15. Crustouse lichens. Identified with Old Nkrigom M1-B

16. Lichens Pertusria sp. One species in genus Pertusria. (Pertusariaceae). Identified with Old Nkrigom M. 1-A.

Viles(1995) discussed the frameworks for describing lithobiontic rock surface communities and suggested that, one of the best frameworks was the one proposed by Golubic et al. (1981). They divided the rock surface community of microorganisms into epiliths (those existing entirely on the surface); euendoliths ( those actively boring pitting into the rock surface); chasmoendoliths ( those living in fissures and cracks); and cryptoendoliths (those occupying pores spaces below the rock surface). These term supersedes the commonly used threefold classification into epiliths; endoliths; chasmoliths. (Viles 1995) described that not all organisms fit into this classification because many lichens are partly endolithic and partly epilithic and several cyanobacteria (formerly known as bluegreen algae, are autotropic bacteria) capable of a variety of growth forms.

For the benefit of proper evaluation of the organisms as they exist on the monoliths it was necessary to adopt (Konhasuser et al, 1994) method of classification, "Biofilm, biorind, and biocrust".

The term biofilm is commonly used to refer to association of microorganisms (but not lichens), largely epilithic, and their mucilage growing on a range of substrate, especially in fluvial environments Konhauser et al (1994). The biofilms constitute mainly bacteria, algae, fungi. And have been found to play a role in the dissolution and precipitation of various minerals. There seem to be no clear agreement over the exact meaning of the term "Biofilm" with some authors such as Westall and Rince (1994) restricting to the mucus of exopolymeric substance (EPS) surrounding bacteria; and 
other using it to refer to entire microorganisms/EPS assemblages. The term biofilm is peharps best restricted to thin accumulations of microorganisms found either in epilithic or cryptoendolithic situations (say $<1 \mathrm{~mm}$ or so) (Viles, 1995).

Biofilm may well play a key role in deterioration on many monoliths surfaces. They form a skin of organisms, mucal slime, mineral particle and organic salts. De la Torre et al (1993) found biofilm 1-2 $\mathrm{mm}$ thick on sand stone, granite and limestone from Spanish monuments dominated by fungi and obviously play a role in mineral transformations on the stone surface. Warscheid et al (1992) studies of monuments from Brazil and Germany suggest that bacterial and fungal rich biofilms modifying the water holding properties of the rocks and may, therefore play a vital role in salts and freeze-thawing weathering. A new term "biorind" is proposed by Viles (1995), for rather thicker associations of microorganisms and lichens, often including euendolithic, chasmoendolithic, cryptoendolithic and epilthic organisms. These biorind are characteristically $1-5 \mathrm{~mm}$ thick, and be involved in both weathering and precipitation of minerals. The term "biocrust" as described by Viles (1995) may be applied to even thicker layers of lichens and microorganisms such as mosses and liverworts $(>5$ $\mathrm{mm}$ ), where the bioconstructive role dominates. Viles pointed out that these terms should really be regarded as points along a whole spectrum of lithobiontic communities.

\section{ECOLOGICAL CONDITIONS OF MICRO-ORGANISMS}

Blue-green algae were dominantly found in every monolith at Old Nkrigom. It was obvious that algae in the dry and rainy seasons are not much different because blue-green algae have mucilaginous appearance on the monoliths. Other organisms then developed on the surface and superimposed on the algae. Ferns and grass start to grow in rainy season. Their growth on some monoliths indicates much moisture retention on the weathered surface. At Alok more genera of fungi were observed in the rainy season than in the dry season.(Fig. 6). Lichen growth on sandstone rock monolith survive very well in extremely dry atmosphere. Their growth cause unsightly appearance. The growth not only obscure the carving and details of the structure but also affect the stability and durability of the monolith. Biological growth is always associated with moisture retention. To a certain extend, the heat permeability and moisture content of the monoliths, is a property which in a certain sense offer the microorganisms latent warm moist conditions, an affinity for growth. Mineral elements from the petrographic composition of the monoliths such as iron $(\mathrm{Fe})$, magnesium $(\mathrm{Mg})$ may act as the substrate base for microbial growth.

Physical data from both sites could attest to the difference on site conditions which give rise to the terms "cool" and "warm", quantitative indicator of the differences in site conditions.

The physical and nutritional conditions of the two sites becomes the yard-stick for growth selection of organisms and those that best adapt to the two different conditions, the open and close forest sites. From observation, the Old Nkrigom forest is restrictively inhabited largely by mosses and liverworts. The Alok open environment support growth of many different micro-bial species, but lichens are predominant. High degree of humidity and moisture in trees, dead wood and monoliths favor contact and growth. Lichens - hybrids produced by fungus and alga were observed in heavy patches causing more damage by rooting on the monolith surface. And mosses growth and bacteria rotting of the tree bark, such as the palm trees were common around the site 


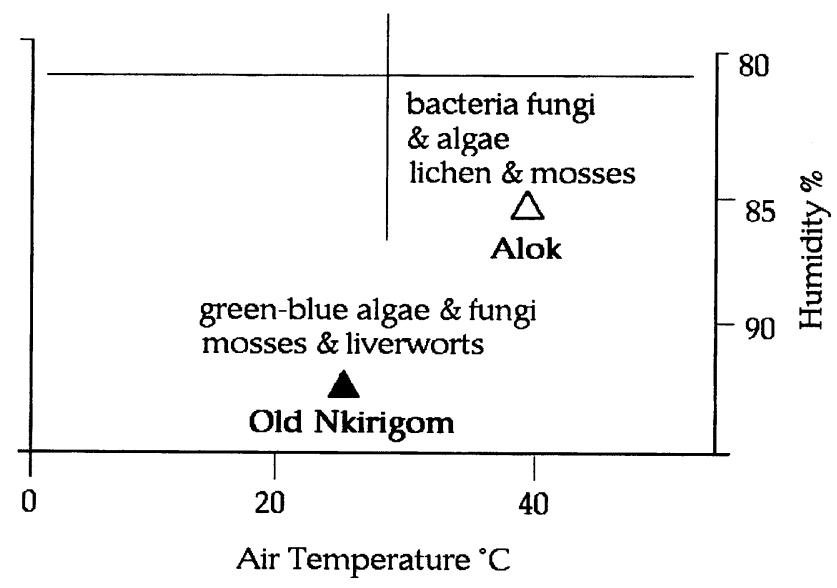

Fig.6. Significant environmental parameters a function to dispersal, and vareity of growth.

The temperature variation play important role in the physico-chemical weathering processes in concert with the micro-organisms. The highest surface temperature of basalt stood at $50^{\circ} \mathrm{C}$ in November 1996, the highest values can be attainable in February, the hottest period. The rate of absorption of solar radiation by the monoliths show a wide contrast between the sites. Alok open site attain higher values because of direct exposure. Old Nkrigom have low values because of the heavy canopy cover. These qualitative and quantitative values of solar radiation also have its relationship with growth type and rate of growth. The spectral composition of the radiation and the duration assume important dimension in the metabolism of micro-organisms.

An important issue became apparent in the study of the micro environment of the sites. This was the environmental changes and microbial responses particularly during the seasonal transition period (Fig. 7). This reaction in the environment involves a change in quantity of water, heat, and the effects of $\mathrm{pH}$ which is known to have a considerable effects on metabolism and on selection and life of species growth on the monoliths. This inturn have impact on the weathering activity that appear as micro cracks and pitting. A change in $\mathrm{pH}$ of the metabolic fluid may engender a transient disruption of the metabolic balance in the system that may cause a slow-down of monolith surface damage efficiency. This may be the cause of the slow and abstrusive cracks and pitting development. As with $\mathrm{pH}$ changes, the temperature changes plays a major role in determining the selection of species and the rate of any chemical reaction.

Temperature changes generally do not occur as abruptly as some of the other type of shock such as water depletion. Temperature is one of the parameters that controls the growth rate of the microorganisms and it is said to effect the enzymatically controlled functions within a cell of a microorganism (Gaudy et al, 1981). At Old Nkrigom forest site, temperature changes usually occur more slowly. At Alok open site it was observed that seasonal change in temperature often bring about the more rapid biochemical response of a large percentage of bacteria species present at the time of temperature change (Fig. 8). 


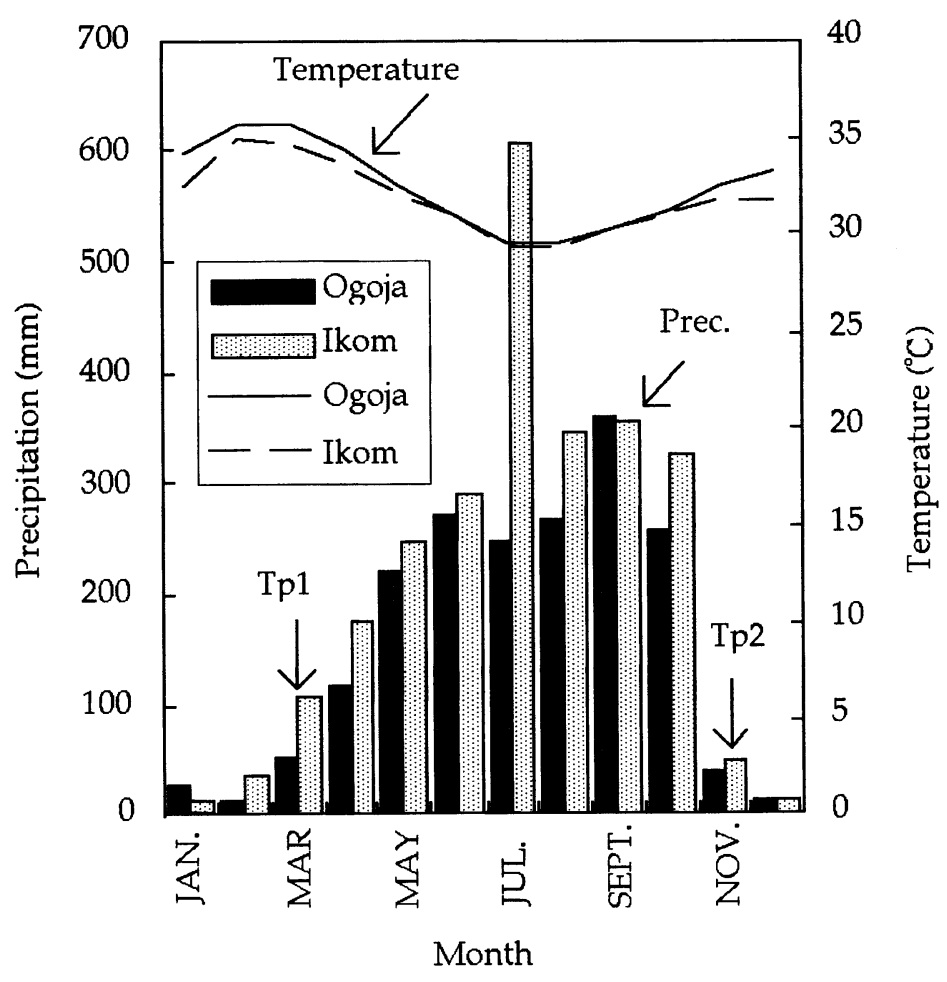

Fig. 7. Ikom \& Ogoja monthly mean rainfall and temperature variation 1973 - 1990. $\mathrm{Tp}$ - seasonal transition period

\section{WEATHERING ACTIVITIES OBSERVED ON SITES}

Accurate estimation of the micro-organisms biomass are difficult to obtain since they proliferate close together and superimpose themselves. The prime objective was to formulate mathematical expression that describe the biomass accumulation. (Edet, 1997). This form the basis for identification and quantification of growth type and accumulation. The grid cell method of estimation applied for this research are not estimation of annual coverage but are used to indicate micro-organisms biomass on the monoliths. Taking an entirely practical approach we plotted each monolith by grid system . A plot of the result is shown in (Fig.9). Such method of measurement are practically useful in the estimation of surface accumulation and types.

Yatsu (1988) described the activities of micro-organisms as efficient decomposers. From the biochemical point of view, decomposition processes may comprise leaching, catabolism and comminution. The monoliths lost their original geological location because, many years ago it was quarried, relocated and used as cultural artifacts. They now experience different vegetation and physical environment. The role of organisms in weathering of these monoliths takes a wider dimension as viewed on the monoliths and trees around the sites. The mineral composition of the monoliths are decomposed by micro-organisms exuding organic acids for their metabolism and releasing enzymes to enhance the chemical reactions. In this study bacteria organisms were not 


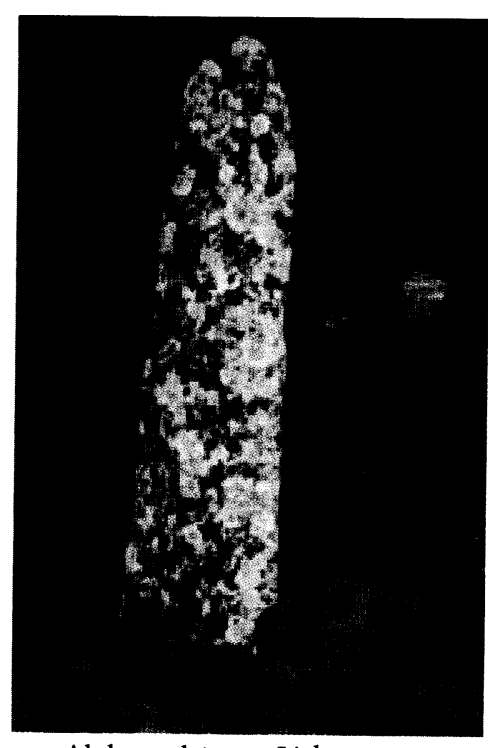

Alok sandstone - Lichens

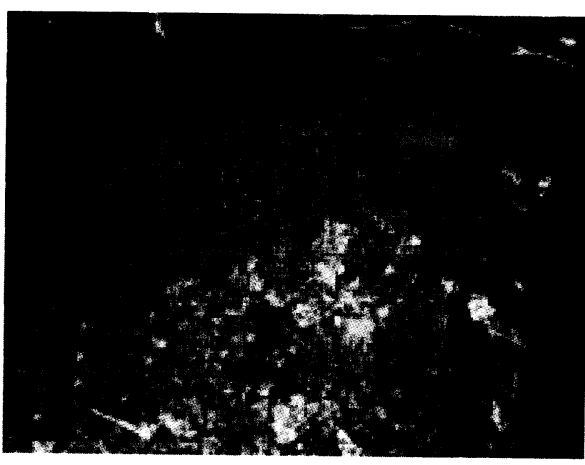

Old Nkrigom basalt - mosses

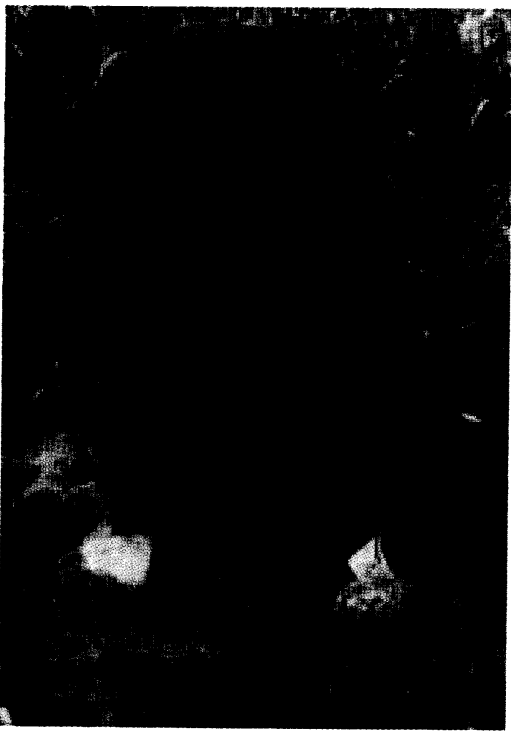

Alok basalt - Bacteria

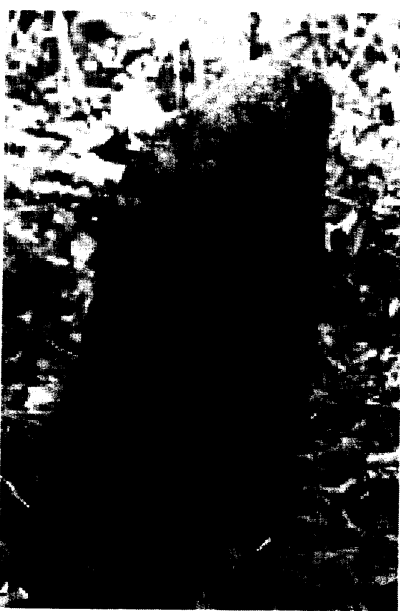

Old Nkrigom basalt - liverworts

Fig. 8. Micro-growth on monoliths at Alok and Old Nkrigom. A: Alok. ON: Old Nkrigom

identified but were observed and generally considered to have contributed largely to the alteration and changes on the monolith surface during metabolic processes. Their coverage on the monoliths proportionally exceeds other micro-organisms. They appear as biofilm while the others are categorize as biorind and biocrust. The growth of algae on the monoliths surface appear blue-green and dark in some monoliths. When touched with the fingers they appear as sticky. Epilithic algae grow on the surface of the rock. Chasmolithic algae reside inside preformed pores or cavities of the rock. Caneva et al. (1992) described epilithic and chasmolithic algae weathering activity as retaining water which can weaken rock surface, penetrating into the surface of substrate and forming micro-cavities.

The chemical and mechanical actions of lichen is observed to take place on all the sandstone 


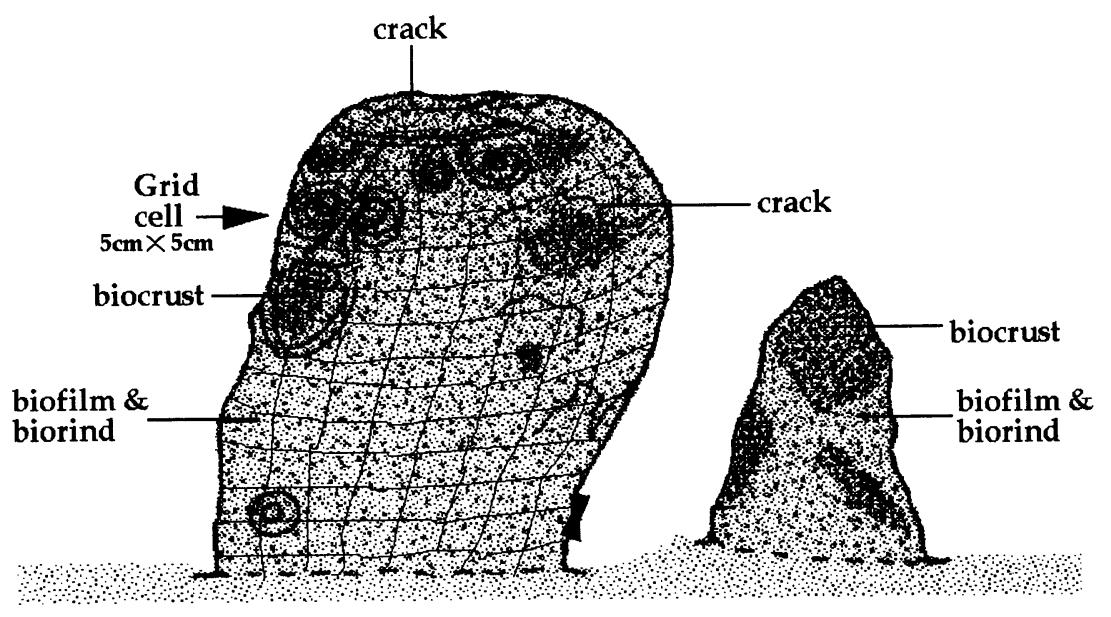

Fig. 9. Evaluation of deterioration using grid system.

monoliths, with heavy patches on basalt. Most of the sandstone monoliths are undecorated and have lose their integrity. Fry (1924) described the resultant mechanical action of a lichen thallus on a rock substrate as pits and fissures. The mechanical action is due to the expansion and contraction under moist conditions and shrinkage under dried condition. Mineral fragments are detached from the rock surface and adhere unto the thallus of lichen during this activity. The chemical actions which is considered the most important involves, the generation of carbonic acids, the excretion of oxalic acid and the production of water-soluble lichen compounds which are able to form soluble metal complexes. Carbon dioxide produced by respiration dissolves itself in the moisture held by thallus and forms carbonic acid that may weather the rock surface. This form of hydrolithic process take place with the destruction of minerals through the depletion of basic cations $\mathrm{Mg}^{++}$, leading to the accumulation of iron on the monolith surface.

The behavior of mosses and liverworts on the Old Nkrigom monoliths are particularly of a chemical nature. Although they have no real roots, their rhyzines hair-like structure are rooted firmly on the existing micro cavities pre-developed most by algae and fungi. Their capacity in extracting mineral cations because of the high acidity of their roots from monoliths surface explain why the monolith surface appear leached and pitted. The growth of ferns and grass on a number of monoliths especially in the rainy season contribute to deterioration mechanically and chemically. The plant tend to grow on cracks and crevices rooting firmly. The tips of absorbing roots always have acidic reaction due to their own negative charge, which is balanced by $\mathrm{H}^{+}$ions and other cations. The acidity is responsible for the etching of minerals particles as $\mathrm{H}^{+}$ions can be replaced by cations in solution following the lytropic series $\left(\mathrm{Ba}^{++}>\mathrm{Ca}^{++}>\mathrm{Mg}^{++}>\mathrm{Cs}^{+}>\mathrm{Rb}^{+}>\mathrm{NH}_{4}^{+}>\mathrm{K}^{+}>\mathrm{Na}^{+}>\mathrm{Li}^{+}\right)$. The transfer of cations occurs through a network of colloidal particles by a contact-exchange mechanism (Caneva et al, 1992) described plant rootlet as mechanism of contact-exchange by which the transfer of cations occurs. Keller et al. (1952) described root exudates to contain both organic and inorganic compounds such as carboxylic acid, nitrogen compounds and acids that have chelating ability. 
The presence of a great number of trees in Old Nkrigom poses serious problem from the expansion of the roots system which eventually affect some of the monolith. The forest vegetation give rise to the risk of perennial fire especially in the dry season. Exposing the monoliths to new forms of microorganisms after fire incidence.

\section{RESULTS}

Micro climate contribute largely through, by seasonal variation and daily ambient conditions. Micro growth is more prominent in warm and humid zones of the sites, but much less in dry zones. The seasonal conditions throughout the year induce relevant variations of synthetic species. High humidity enables bacteria, lichens, mosses and liverworts growth. Low humidity in the dry season promotes the dryout of the monolith surface particularly in Alok site. Relative humidity during the rainy season on average $96 \%$, during the dry season on average $85 \%$. Daily fluctuation from $98-80 \%$.

Alok and Old Nkrigom tend to have a wide range of growth of micro-organisms. Comparison of the two sites showed significant similarities and differences. Firstly, the lack of abundant growth of micro organisms on monoliths that are not under canopies due to high solar temperatures. Secondly, thickness of growth appear in uniform and fairly consistent for monoliths on both sites under canopies, with greater effect on monoliths under Old Nkrigom canopies. Moisture and sunlight tolerance may be the explanation for the difference in magnitude of distribution of the species between the two sites. During the transitional period, from dry season to wet, (March to April), a wide variety of organisms appear as new growth on the monoliths.

Our data indicated that five groups of mosses associated with Old Nkrigom while two groups were found in Alok (Table 1). Lichens was greater in stands on Alok monoliths, than Old Nkrigom, this difference may be a function of several factors. Growth characteristics were comparable between monoliths of different lithology. Micro-climate within and around the sites may have contributed to the different in rate of growth and percentage of growth. The thermal properties of the monoliths may be important for growth of micro-organisms. Sustained growth of lichen and mosses particularly in the dry season were observed more on sandstones than in basalt. This may be attributed to high moisture content and lower surface temperature in sandstone than basalt.

We make predictions about the probable influence of rock lithology on micro growth. Because of the difference in growth rate and pattern between the sites. Lichen growth and establishment on Old Nkrigom monoliths may have been suppressed in dense stands due to decreased light quantity and quality. Variation in growth has been observed as a factor controlling the type of development. Diversity and abundance of lichens growth at Alok site are linked to physical factors such as optimum air temperature, sunlight and monoliths surface temperature. It was observed that lichens are more abundant at Alok monoliths and plants and in the edges of plants that adjoin Old Nkrigom forest than in its interior forest where the monoliths are located. Influence on lichen growth at Old Nkrigom suggest that the micro-climate is not suitable for the prolific growth of lichens.

Investigation of the surface temperature and moisture of the monolith structure contribute to an understanding of the mechanism of biodeterioration. The surface moisture content and the growth of microorganisms are features which have relationship with the surface temperature of the monoliths. A temperature of $60^{\circ} \mathrm{C}$ is usually given as the thermal death point for most plant tissues. But this value 


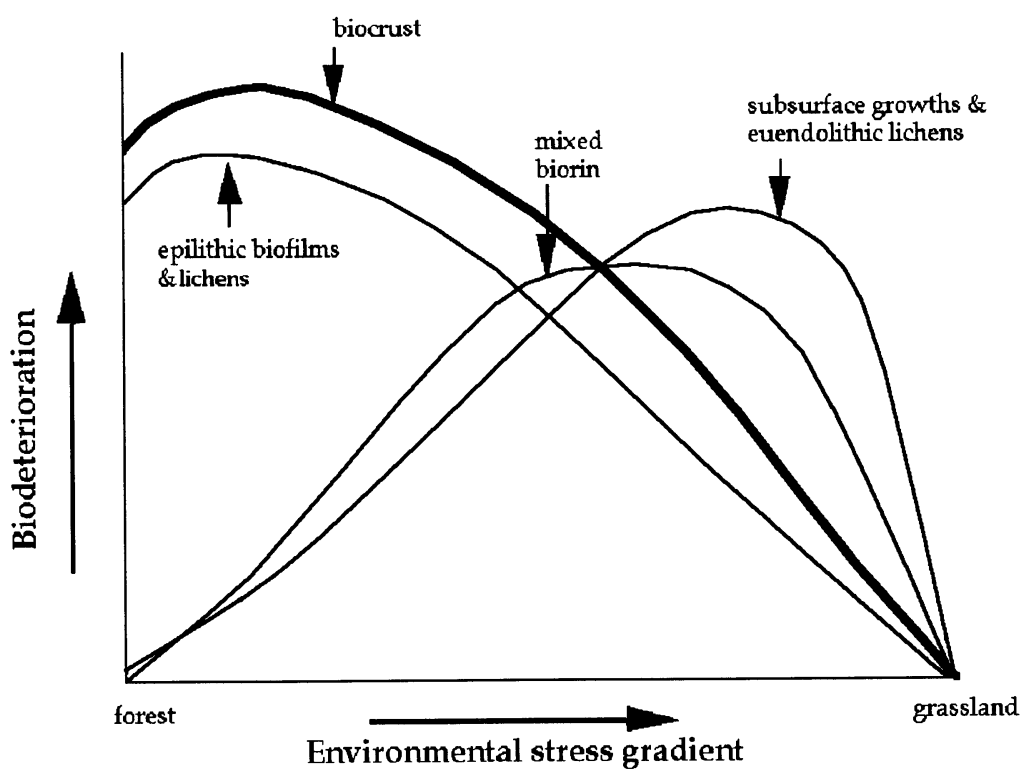

Fig. 10. Schematic diagram of changing effectiveness of biodeterioration on various rock across an environmental gradient.

does not seem to affect micro-organisms such as lichen. Death of plant tissues will depend on moisture content and is an exponential function of temperature and time. Salt, sugar, lignin and pectin are other variables that might be involved in the tolerance of plant tissues against high temperatures. (Fig.10) show a schematic diagram of the changing effectiveness of biodeterioration of microgrowth on rocks across an environmental gradient between the sites.

\section{CONCLUSION}

This study addressed the influence of micro-organisms via comparison of the two sites. Our results indicate that in Alok, lichens and mosses species are associated more with Alok sandstone and are more effective at dispersal and colonization which lead to so much surface alterations and the erosive damage to the rock monoliths. The basalt are more exposed to extensive bacteria, fungi and algae cover, and heavy patches of lichen growth particularly towards the top of the monoliths and on the surface area facing east. Alok monoliths tend to have favorable combination of its thermal properties which is conducive to high surface temperature that enhance lichen growth. Thermal properties of sandstone and basalt is major contributor in daily and seasonal regulation of biological changes that orchestrate the process of chemical weathering. Correct identification and characterization of the micro-organisms assist in tracing the origin of the pitting and micro fissures.

ACKNOWLEDGEMENTS Acknowledgement is made to Professor Dr. T. Tsujii of Hokusei Gakuen University for his encouragements. The assistance of Mr. M. Hanaoka is gratefully acknowledged. Further acknowledgement is made to OSSTECH Nigerian Limited for their technical 
assistance and cooperation in the field. And to the National Commission for Museums and Monuments for permission to undertake this study.

\section{REFERENCES}

Allison, P. 1968. African Stone Sculpture. Frederick, A. Praeger. New York.

Caneva, G., Gori, E. \& Danin, A. 1992. Incident rainfall in Rome and its relation to biodeterioration of buildings. Atmos. Environ. 26B: 255-259.

De la Torre, M. A., Gomez Alarcon, G. \& Palacios, J. M. 1993. In vitro biofilm formation by Penicillium frequentants strains on sand stone, granite and limestone. Appl. Microbiol. Biotechnol. 40: 408-415.

Edet, A. S. 1997. Deterioration of the Cross River Monoliths. Alok and Old Nkrigom Sites, Nigeria. M.Sc Thesis Hokkaido University, Japan.

Fry, E. J. 1924. A suggested explanation of the mechanical action of lythphytic lichens on rocks (shale). Annals of Botany 38 (149): 175-196.

Gaudy, A. \& Gaudy, E. 1981. Microbiology for Environmental Scientist and Engineers. Mc Graw-Hill International. Auckland.

Golubic, S. , Friedmann, E. \& Schneider, J. 1981. The lithobiontic ecological niche, with special reference to microorganisms. J. Sediment. Petrol. 51: 475-478.

Giulia, C. \& Salvadoir, O. 1988. Biodeterioration of stone. In:: Lorenzo, L. \& Pieper, R., eds., The deterioration and Conservation of Stone. Notes from the International Venetian Courses on Stone Restoration,182- 241. Roma, Italy.

Keller, N. D. \& Frederickson, A. F. 1952. The role of plants and colloid acids in the mechanisms of weathering. American Journal of Science 250: 594-608.

Konhauser, S. O., Schult, L. K., Ferris, F. G., Fyfe, W. S., Lonstaffe, F. J. \& Beveridge, T. J. 1994. Mineral precipitation by epilithic biofilms in the Speed River, Ontario, Canada. Appl. Environ. Microbiol. 60: 549-553.

Pievittori, R., Salvadori, O. \& Laccisaglia, A. 1994. Literature on lichens and biodeterioration of stonewor1. Lichenologist 26: 171-192

Udo, R. K. 1970. Geographical Regions of Nigeria. Heinmann London. U.K.

Viles, H. 1995. Ecological perspectives on rock surface weathering: Towards a conceptual model. Geomorphology 13: 21-35.

Warscheid, T., Barros, D., Becker, T. W., Braams, J., Eliasoro, S., Grote, G., Janssen, D., Jung, L., Masarenhas, S. P. B., Mazzoni, M. L., Petersen, K., Simonoes, E. S., Moreira, Y. K. \& Krumbein, W. E. 1992. Biodeterioration studies on soapstone, quartzite and sandstone of historical monuments in Brazil and Germany. In: J. Delgado Rodrigues, F. Henriques, F. \& Telmo Jeremias eds., Proc. 7th Int. Congr. on Deterioration and Conservation of Stones, 491-500. Laboratoria Nacional de Engenharia Civil, Lisbon.

Westall, F. \& Rince, Y. 1994. Biofilms, microbial mats and microbe-particles interactions: electron microscope observations from diatomaceous sediments. Sedimentology 41: 147-162.

Yatsu, E. 1988. The Nature of Weathering: An Introduction. Sozosha, Tokyo, Japan.

Received April 10, 1999

Accepted December 23, 1999 


\begin{abstract}
Abu S. Edet, 高橋英紀, 関太郎
ナイジェリア, クロス河流域の玄武岩石像群の 表面劣化に及ぼす微生物の影響

ナイジェリア南東部を南北に貫流するクロス河流域の 34 の地域に玄武岩を主な母材とした総数 450 以上 におよぶ石像が分布する遺跡群がある。石像は高さ0.3-2 m, 重さ 200-800 kg の円柱状で, 表面には人 面あるいは人体を抽象化した美しい彫刻が施されている。住民はこの石像を祖先の象徴として崇めており, 現在でも地域社会において重要な役割を担っている。この石像遺跡群の成立については不明な点が多いが, 文化遺産としても人類学・考古学的にもナイジェリアあるいは中・南アフリカにとって極めて重要である。

この遺跡群は熱帯雨林地域の縁辺部に分布するため, 森林の耕地化にともなう急激な微気象の変化にさ らされている。本研究では, 熱帯雨林地域 (Old Nkrigom 地区) と森林伐採後に草原となった地域(Alok地 区) に存在する各 1 ヶ所の石像遺跡を対象に，微気象観測を行うとともに，石像の表面に付着繁茂する多 様な微生物と, それらが遺跡の劣化に及ぼす影響について研究を行った。その結果, Old Nkrigom にお いて蘚類 6 種, 苔類 2 種, 地衣類 4 種を, Alok では蘚類 1 種, 地衣類 3 種が同定された。また, 石像表面 における微生物の生長や堆積を調査し, 石像劣化との対応についても検討した。その結果は各種の微生物 が代謝作用で分泌, 沴出する有機物質あるいは化学物質による石像表面における複雑な生化学的風化作用 の存在を示唆するものであった。
\end{abstract}

